\title{
CASADA CONSIGO MESMA: MULHERES PALHAÇAS E A BUSCA DE UMA COMICIDADE FEMINISTA
}

\author{
MARRIED TO HERSELF: WOMEN CLOWNS AND THE SEARCHOF A FEMINIST COMIC
}

\begin{abstract}
RESUMO
O presente artigo realiza uma reflexão acerca da intervenção artística de palhaças “Casada Consigo Mesma”, criada pela Cia. Asfalto de Poesia. São subsídios para esta análise: o histórico da presença das mulheres na arte da palhaçaria, o estudo dos recursos específicos da linguagem da palhaçaria, as ideias de comicidade e riso e o conceito de paródia. Investiga-se os recursos empregados para a criação de repertório e a consequente renovação da dramaturgia existente nesta linguagem, esboçando o conceito de uma comicidade feminista. Também se analisa as maneiras pelas quais a intervenção artística desestabiliza as imposições ao gênero feminino referentes à instituição do casamento e a padrões de beleza, consolidando-se como uma ferramenta para experiências de uma comicidade feminista.
\end{abstract}

Palhavras-chave: Mulher. Palhaçaria. Casamento. Comicidade feminista.

\begin{abstract}
This article presents a reflection about the artistic intervention of clowns "Married to herself" [Casada consigo mesma], created by Cia. Asfalto de Poesia. The subsidies for this analysis are: the history of the presence of women in the art of clowning, the study of the specific features of the language of clowning, the ideas of comic and laughter and the concept of parody. The resources used for the creation of repertoire and the consequent renewal of the dramaturgy existing in this language are investigated, outlining the concept of a feminist comic. It also examines the ways in which artistic intervention destabilizes the impositions on the female gender regarding the institution of marriage and beauty standards and consolidates itself as a tool for practical experiences of a feminist comic.
\end{abstract}

Keywords: Woman. Clowning. Marriage. Feminist comic.

\section{Introdução ${ }^{1}$}

As palhaças estão presentes em diversos locais: teatros, circos, praças, hospitais. Porém, a figura da palhaça ainda causa certo estranhamento. Isso porque

\footnotetext{
1 Este artigo é resultado de minha dissertação de Mestrado em Artes - Estética e Poéticas Cênicas (Unesp) defendida em 2017 sob orientação do Prof. Dr. Mario Fernando Bolognesi e intitulada "Olha a palhaça no meio da praça: Lily Curcio, Lilian Moraes, questões de gênero e muito mais!”.
}

Maria S. Do Nascimento

Palhaça e Pesquisadora - Brasil. E-mail: mariasilvia.nascimento@gmail.com 
no imaginário coletivo e na história das artes cênicas, o palhaço se consolidou como figura prioritariamente masculina.

Enquanto pesquisadora, arte-educadora e também palhaça, confrontei-me com diversas discussões acerca do "feminino" na palhaçaria. Diversas vezes fui chamada de "palhaço" por crianças ou questionada se, de fato, era mulher ou homem. Já os adultos tinham certa timidez em denominar-me palhaça, pois, infelizmente, essa palavra adquiriu sentido pejorativo. Nos debates entre artistas, a presença de mulheres na palhaçaria ainda é polêmica, pois, mesmo que não sejam deliberadamente excluídas, elas ainda sofrem os resquícios de séculos de apagamento nessa arte.

Apesar de um tema pouco evidente, investigações acerca de mulheres palhaças já estão sendo desenvolvidas por diversas pesquisadoras e divulgadasem revistas acadêmicas ${ }^{2}$, sites,blogs, festivais ${ }^{3}$, encontros e debates dedicados a dar voz às palhaças.Ações que, tomadas em conjunto,indicam uma movimentaçãodas mulheres a fim de legitimarem sua atuação como palhaças.

Neste artigo, procuro dar minha contribuição por meio de uma investigação situada tanto no campo teórico - confrontando, por um lado, as teorias do riso e da palhaçaria e, por outro, analisando aspectos dos repertórios de diversas palhaças atuantes -, quanto em minhas próprias experimentações artísticas. Sobre este último ponto, desenvolvi, junto à Cia. Asfalto de Poesia ${ }^{4}$, a intervenção Casada Consigo Mesma $a^{5}$, na qualbuscamos uma comicidade feminista unindo as linguagens da palhaçaria ${ }^{6}$, as experimentações de intervenção de rua e algumas reflexões acerca de questões de gênero.

2 Michelli Silveira da Silva (Chapecó-SC) criou a revista Palhaçaria Feminina, em sua quarta edição.

3 Por exemplo, até 2017, "El Festival Internacional de Pallasses de Andorra", que teve início em 2001 e contou com três edições até 2009, em Andorra; o Ciclo de Mulheres Palhaço promovido pela Companhia Teatral Chapitô, em Lisboa-Portugal, com edições anuais de 2008 a 2013; os ciclos "Very important women" no espaço "Armazen" em Barcelona-Espanha; "Clownin", festival de mulheres palhaças que ocorreu na Áustria bienalmente, de 2006 a 2012; o "Red Pearl Festival" na Suécia e Finlândia, com edições em 2012, 2013, 2014, 2016. No Brasil: o "Festival Internacional de Comicidade Feminina - Esse Monte de Mulher Palhaça", organizado pela Cia. As Marias da Graça, no Rio de Janeiro, com edições em 2005, 2007, 2009, 2012, 2013, 2016; o "Encontro de Palhaças de Brasília", organizado pela palhaça Manuela Mathusquella, com edições em 2008, 2010, 2012, 2014, 2016, 2017; e o Festival Palhaçaria de Recife organizado pela Companhia Animée que ocorreu em 2012, 2014, 2017; e o Encontro de Mulheres Palhaças de São Paulo em 2013, 2014, 2016, 2017, realizado pelo Teatro da Mafalda.

4 Companhia de teatro que investiga as máscaras teatrais, principalmente, a palhaçaria e está em atividade desde 2007, na grande São Paulo-SP.

5 A intervenção Casada Consigo Mesma foi idealizada a partir da vivência proposta na Ocupação Mulheres, Performance e Gênero pelos coletivos Dodecafônico e Rubro Obsceno, na Oficina Cultural Oswald de Andrade, em São Paulo-SP, em 2016.

6 A configuração da arte da personagem palhaço é atribuída à união de diferentes matrizes de personagens cômicos europeus, entre elas, o clown das pantomimas inglesas e as máscaras da Commedia dell'Arte (principalmente a do Arlequim), figuras que se intercambiavam no contexto dos teatros de feira europeus, do final do século XVIII. A palhaçaria consolidou-se no circo, mas como linguagem múltipla também ocupou o teatro cômico. Usa, predominantemente, a comicidade física e agrega recursos como acrobacia, dança e música em seu desempenho. 


\section{A intervenção Casada Consigo Mesma}

A noiva é aguardada por um pequeno altar florido, decorado com flores de plástico e um espelho,em frente a um teatro, centro cultural ou na rua. A ambientação inclui placas com os dizeres "recém-casada comigo mesma”; "case-se consigo mesma”; "amar sem temer". A noiva será qualquer mulher que aceitar o convite para selar um compromisso consigo mesma.

A cerimônia é celebrada por, em média, três palhaças que usam nariz vermelho, perucas, bochechas avermelhadas e sobrancelhas de diversos tamanhos e formatos (vide figura 1). O figurino das sacerdotisas é composto por vestidos de noivas alguns deles foram de suas mães, outros foram feitos com as cortinas da cozinha de suas casas; outros comprados em brechós por menos de vinte reais. Também usam véus - uns são curtos, outros chegam a medir seis metros de comprimento e são chamados por elas de "rabo". "Segura o meu rabo", solicita uma das palhaças mestras de cerimônia.

A noiva escolhe uma música de sua preferência. Pode ser tanto o célebre Tãtã-tã- Tã, Tãtãtã Tã (Marcha Nupcial), quanto diversas outras músicas a escolha da pessoa mais importante desse dia. As palhaças reproduzem a música com seus instrumentos musicais inusitados e cantam em coro algumas paródias como "eu sei que vou me amar, por toda minha vida vou me amar"7; ou ainda canções internacionais em línguas ininteligíveis.

A noiva percorre o tapete roxo que demarca sua trajetória rumo ao encontro com a pessoa mais importante de sua vida: ela mesma. Uma palhaça anuncia:

- Hoje é o dia mais importante de sua vida, o dia que você esperou desde pequena, que todas as pessoas se perguntavam quando seria, que todas as novelas mostravam que era a realização de um final feliz... Hoje é o dia em que você vai se casar com a pessoa mais importante da sua vida, aquela que sempre esteve e sempre estará ao seu lado que é... Você mesma! Palmas.

A mestra de cerimônias pede para que a participante responda às perguntas que lhe serão feitas, olhando diretamente para seus próprios olhos no espelho:

- Você, (dizendo o nome da participante), promete amar-se e respeitar-se na saúde ou na doença? Você promete se amar mesmo com uns quilinhos a menos ou a mais? Com rugas a menos ou a mais? E sabe que esse negócio de a mais ou menos não existe porque não temos que seguir os padrões? Você promete sempre se sentir capaz, não importa o que os outros digam?

Algumas participantes hesitam em responder e, assim, se pode perceber o conflito que tal pergunta gera nas mulheres. Outras respondem rapidamente, com a convicção de quem já passou por tais questionamentos em suas experiências de vida.

- Promete amar-se por todos os dias de sua vida? Você promete acariciar-se, apalpar-se, estimular-se todos os dias? Se esquecer num dia, promete compensar no outro? Todas as palhaças dão gargalhadas, sublinhando o duplo sentido das frases.

7 Paródia da canção "Eu sei que vou te amar" de Tom Jobim e Vinicius de Moraes. 
Então, uma das palhaças exemplifica com uma flor de plástico, com formato parecido com o de uma vagina, como tocar o amor por si mesma, aludindo à masturbação.

A pergunta derradeira: "Você se aceita?". E, mais uma vez, alguns momentos de hesitação ou euforia até o tão esperado "sim” . "Então, eu a declaro: casada consigo mesma!”. Palmas, assovios e gritos.

Mais algumas regras do matrimônio são enumeradas. "O casamento consigo mesma é poligâmico. Uma vez que você se casa consigo, pode se casar com quem quiser. Porém, não há divórcio! Sabemos que é quase impossível estar sempre em harmonia, às vezes, dá aquela vontade de se separar de si, mas temos que acreditar, o que a gente juntou nunca mais poderá se separar".

As palavras sagradas são seguidas pelo choro descontrolado das palhaça que esguicham, literalmente, lágrimas sobre a noiva e convidadas. Depois jogam arroz e fazem o ritual do buquê: a noiva coloca-se de costas para o público e joga o buquê para trás. Há uma grande confusão, com palhaças tropeçando, levando bofetões e caindo no chão, com as pernas abertas e mostrando sua roupa íntima espalhafatosa.

Após o ritual, a noiva assina o pergaminho com seu nome, onde constam os nomes de todas as mulheres que aceitaram se casar consigo mesmas. Depois de uma série de casamentos realizados, é hora da comemoração. Chegam os pratos de bolo que são oferecidos às participantes, porém, ao final, tudo se transforma em uma apoteótica cena de "torta na cara" entre as palhaças.

\section{Histórias de palhaças}

Grosso modo, pode-se dizer que as mulheres palhaças começaram a ganhar visibilidade após a década de 1970, com o advento das escolas de circo $^{8}$ e com a (re) aproximação das escolas e artistas de teatro das artes circenses, principalmente, da

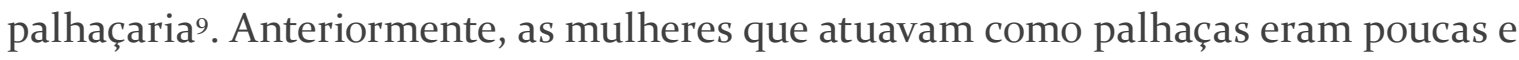

\footnotetext{
8 Academia Piolin de Artes Circenses funcionou de 1978 a 1982 na cidade de São Paulo; Circo Escola Picadeiro, fundada por José Wilson Moura Leite em São Paulo em 1984; Escola Nacional de Circo criada em 1982 pelo Governo Federal na cidade do Rio de Janeiro; Escola Picolino de Artes do Circo fundada por Anselmo Serrat e Verônica Tamaoki em 1985 na cidade de Salvador-BA (SANTOS, 2014). O mesmo período é considerado na França como início do "circo contemporâneo", no qual há uma mudança no espetáculo, que passa a agregar diferentes linguagens e algumas mudanças como a restrição à utilização de animais.

9 Mario Bolognesi (2006) enumera as principais correntes de pesquisa: uma advinda diretamente do estudo com palhaços circenses, também nas escolas de circo; outra feita pelo grupo LUME (CampinasSP) liderado por Luis Otávio Burnier que estudava máscaras como uma passagem da pré-expressividade para a expressividade; e os trabalhos de Maria Helena Lopes (UFRGS), Elizabete Lopes (Unicamp) e Francesco Zigrino (diretor italiano que lecionou oficinas de clown na Escola de Artes Dramáticas da USP nos anos 1980), concepções "filtradas" dos diretores franceses Jacques Lecoq (1921-1999) e Étienne Decroux (1898-1991).
} 
se caracterizavam como palhaço (homem) ${ }^{10}$ ou como uma figura considerada neutra ${ }^{11}$. Essas exceções confirmam a regra: o território da arte da palhaçada esteve dominado pelos homens durante os mais de dois séculos de sua existência ${ }^{12}$.

Dentro do universo das artes cênicas, a partir da modernidade, as mulheres não foram proibidas de estar em cena, ou seja, de estar no espaço público. No entanto, foram coagidas a representar um universo restrito de papéis, que refletia a forma de feminilidade aceita socialmente, tanto pela visão do respeitável público quanto pelos limites do palco e da cerca do circo. Ser palhaça, não estava nesta lista de permissões ${ }^{13}$.

Aparentemente, poderia se tratar de um papel de mesma natureza e finalidade que os demais dentro do espetáculo: expor seu corpo e voz para divertir o público. Porém, a arte dapalhaçaria envolve qualidades específicas: o lugar do improviso, o contato direto com o público, ser sujeito do riso, ter liberdade com o corpo e com a sexualidade. A palhaçaria também inclui o fazer rir e não ser apenas objeto de zombaria; dirigir-se ao público sem intermediários e de acordo com sua subjetividade; manipular o prazer do riso, tanto seu próprio prazer quanto das demais pessoas; apresentar um corpo próximo ao grotesco, conectado com o mundo exterior e livre dos ideais de umabeleza que se encerra em si e deve ser contemplada (uma espécie de voyerismo).

\section{Arte da palhaçaria}

E a palhaça, o que é? São diversas as abordagens e nomenclaturas para o que chamamos aqui de arte da palhaçaria.

De acordo com Bolognesi (2003) e Pantano (2007), a personagem palhaço é uma personagem arquetípica, ou seja, segue alguns padrões estabelecidos ao longo da história, o que pode caracterizá-la como uma personagem universal. Basta apresentar alguns elementos chave do palhaço que ele será reconhecido, geralmente: o nariz vermelho, as roupas desproporcionais, uma comicidade principalmente baseada em situações corporais. Há ainda gags, entradas e esquetes típicos que podem ser reconhecidos pelo público e determinar a personagem mesmo que ela não esteja

10 No Brasil, temos o exemplo de Maria Eliza Alves, o palhaço Xamego, que mantinha em segredo o fato de ser mulher. Sua história é contada por sua neta, Mariana Gabriel no documentário Minha vó era palhaço (2016).

11 Annie Fratellini, artista francesa da renomada familia circense Fratellini, dizia que palhaço não tinha sexo e, por isso, construiu uma figura ambígua, mas que prioritariamente, escondia o fato de ser mulher. A imprensa francesa afirmava que Annie Fratellini era bonita demais pra ser palhaço, no entanto, hoje ela é referência mundial nessa arte.

12 São diversas as abordagens do surgimento do palhaço, mas aqui considero a criação do Circo Moderno (final do século XVIII) e a vinda de famílias circenses para o Brasil. Apesar disso, considero extremamente válidas as aproximações da figura do palhaço com outras figuras cômicas históricas como bufões, bobos da corte e outras personagens cômicas e populares.

13 Importante ressaltar que havia diversas figuras cômicas femininas, como as soubrettes, caricatas, clownesses, vedetes, porém, essas não eram alçadas ao status do palhaço dentro da cena. De qualquer forma, seu legado é uma rica fonte para as palhaças. 
caracterizada da forma corrente. Muitas vezes é difícil precisar quais seriam esses elementos e está justamente aí o grande diferencial da arte da palhaçaria.

Contudo, além de uma personagem universal, o palhaço é uma personagem individual. Cada palhaça/o agrega à sua atuação elementos pessoais, criações e características que podem ser próprias do artista: sua voz, seu nome, traços de comportamento, formas de andar, formas de se vestir, maquiagem, entre outros elementos. Essa importância da criatividade do artista para a construção da personagem permite, por exemplo, que surjam palhaços e palhaças tão diferenciados entre si. Assim sendo, cada personagem expressa a subjetividade da/o artista que a compõe. "Nesse sentido, é praticamente impossível escapar de si mesmo ao construir uma personagem [palhaço]" (Pantano, 2007: 52). Sob essa perspectiva, a entrada das mulheres na arte da palhaçaria significou novas experiências de vida - as diversas experiências do ser mulher -, que se misturam à dita palhaçaria clássica e estão revolucionando as formas de se fazer palhaçada.

Além dessa característica marcante, a linguagem utilizada é sempre pautada no corpo. "O clown é um ser que tem suas reações afetivas e emotivas todas corporificadas em partes precisas de seu corpo, ou seja, sua afetividade transborda pelo corpo, suas reações são todas físicas e localizadas (Burnier, 2009: 217). Assim, é preciso que a/o artista esteja em consonância com seu corpo para poder expressarse. Porém, essa qualidade de corpo não se apresenta como um sistema fechado, não se encerra em si. Ele está aberto e em trânsito com o ambiente externo, o que o caracteriza como grotesco (Bakhtin, 20o8). Esse seria um corpo incompleto que se opõe à ideia de perfeição.

O corpo grotesco é ilimitado: pode penetrar e ser penetrado; digerir e excretar fluidos. Seria aquele corpo popular - que tem fome, sede, desejos sexuais - enquanto o corpo belo é individual, encerra-se em si mesmo, sem contatos com os demais. Já nesse ponto encontra-se uma fricção com a construção do corpo feminino em nossa sociedade, um corpo cujas regras e disciplinas excluem o grotesco e acentuam o belo, delicado e frágil.

A arte da palhaçariatambém se caracteriza pelo riso. Ela tem a tarefa do alívio cômico, é a expressão do fracasso, da bobeira, da queda e do erro. Porém, seu fracasso é apenas um jogo. Um jogo no qual artista e personagem são sujeitos e objetos do riso, ou seja, palhaças e palhaços manipulam os recursos para o risível e, ao mesmo tempo, expõem-se a eles. Promove-se a alegria dentro da ideia de "paixões alegres", conceito de Espinosa trazido pela pesquisadora Kátia Maria Kasper para definir a palhaçaria. "A paixão alegre é um caminho em direção à atividade, que consiste em se tomar posse de sua própria potência, em não deixar que nossa potência seja capturada por paixões tristes e poderes estabelecidos" (Kasper, 2004: 36).

Palhaços e palhaças não só fracassam, mas enfrentam o fracasso mostrando sua força vital, superam seu próprio ridículo, encaram-no, mostram-no diante da plateia, transpondo qualquer situação que, se real, causaria sofrimento. Propõem um tipo de distanciamento emocional, constatado por Henri Bergson (2007) como fundamental para o riso. Nada parece grave ou digno de piedade, conseguem transpor situações, 
seja se utilizando da astúcia, da trapaça, seja passando pelas quedas e tapas sem se machucar. Talvez até não compreendam o que se passa consigo e, assim, dão curso à vida naturalmente, ignorando adversidades.

Na linguagem da palhaçaria, a personagem não parece sentir dor, por isso, rimos com ela e não dela. O riso proveniente disso é um riso festivo, pois ele nos remete a um ser que cai e não se machuca; que leva bofetões que não doem; que tem fome, mas não passa fome; que é sozinho, mas não solitário. Para palhaços e palhaças, os tapas não expressam violência, mas apenas um conflito traduzido em gesto. As quedas não são acidentes, mas decorrência da inconstância da vida. Se não parecem sofrer, pode-se rir com eles. Não é preciso achar-se superior a eles, como afirma Bergson (2007), quando deduz que o riso é um processo racional. Basta saber que pra eles tudo é uma brincadeira, um jogo. Tanto é assim que palhaçose palhaças nos fazem chorar quando notamos, num átimo, que talvez o que lhes aconteceu possa provocar sofrimento. É o caso emblemático de Carlitos (Charles Chaplin) que, muitas vezes, apesar de suas cenas cômicas, torna-se emocionante e, também, crítico da sociedade. Como determina Aristóteles (Alberti, 1995: 3), o cômico consiste "em um defeito ou torpeza que não causa nem dor nem destruição”, o cômico está em oposição ao trágico.

Mais do que o erro, a palhaçaria pode representar a transgressão daquilo que seria o correto. O cômico se vale do contraste, do estranhamento e da ruptura. Numa perspectiva freudiana, o riso está próximo ao sonho, trazendo o conteúdo inconsciente (o encoberto e o "não-dito") à tona, por meio de chistes, piadas e paródias.

Para a pesquisadora Katia Maria Kasper (2004), o processo de construção e/ou criação de uma personagem palhaça/o é visto por meio da ideia de "gestos em fuga", baseada nos treinamentos do LUME-Campinas-SP. Para a autora pode-se "pensar no clown, além de uma ampliação, uma dilatação da pessoa, como um potencializador de devires" (Kasper, 2004: 362). Dessa forma, palhaços e palhaças representam também novas possibilidades de vida, também representam o devir e, consequentemente, uma quebra de expectativa, uma resposta não programada aos acontecimentos.

Em entrevistas, muitas mulheres que atuam como palhaças alegam que elas representam "o melhor de si". São suas "novas possibilidades de vida”, uma via para a reinvenção de si (Nascimento, 2017). Uma espécie de catarse cômica que possibilita às mulheres se verem representadas de outras maneiras, tanto para as artistas quanto para a plateia.

\section{Estudos sobre palhaças, comicidade feminina e feminista}

Há uma latente necessidade de (re)construir as narrativas acerca do lugar das mulheres na comicidade em geral e na arte da palhaçaria em particular. Entre os aspectos que merecem consideração estão: a visibilidade e a divulgação de referências; a criação e a adaptação de repertório; o entendimento de processos de 
ensino/aprendizagem; as barreiras enfrentadas pelo gênero feminino; a história das mulheres no circo e no teatro e a importância de eventos com foco em questões de gênero visando à troca de experiências e à criação de uma rede de artistas que valorize a arte da palhaçaria feita por mulheres.

Grande parte da discussão acerca das palhaças traz a expressão comicidade feminina em seus argumentos. $\mathrm{O}$ termo tem o objetivo de estabelecer as mulheres como protagonistas do discurso cômico e, além disso, a comicidade feminina seria composta por "mecanismos cômicos pautados ou tematizados por um universo feminino construído a partir das transformações físicas e sociais operadas pelas mulheres" (Nascimento, 2014: 66). Porém, acredito que a expressão "universo feminino" pode muitas vezes se tornar uma cilada, pois se há um delineamento sobre o universo feminino, ele faz parte de um discurso, é histórico e se modifica com o tempo.

Nesses termos, não há a priori um repertório de palhaçaria que não possa ser realizado pelas mulheres. As mulheres têm as mesmas capacidades de realizar o que é realizado pelo homem. É possível observar que, no senso comum, alguns dos recursos cômicos empregados pela arte da palhaçaria foram classificados apenas como masculinos como tapas, tropeções, cambalhotas, saltos e outras capacidades de acrobacia. Porém, essa seria mais uma falácia, pois eles não se categorizam como próprios apenas dos homens ${ }^{14}$.

A inconsistência de explicações para o impedimento de mulheres como palhaças demonstra que as barreiras femininas não são inatas. As barreiras impostas às mulheres para a atuação cômica estão no campo do aprendizado e da incorporação de discursos, com implicações concretas e objetivas.

As mulheres como protagonistas do cômico, podem modificar substancialmente a comicidade e a arte da palhaçaria, porém, partindo dos pressupostos específico das questões de gênero, elas não produzem uma "outra comicidade", uma comicidade feminina (em oposição à masculina). A comicidade feita por mulheres e homens não seriam assim excludentes, pois se acreditássemos nisso se estaria corroborando com a ideia que retrata as mulheres como essencialmente diferentes e opostas aos homens.

Tomando como base as tipologias de palhaços, na maioria das vezes,suas classificações se referem ao tipo de papel que realizam no espetáculo e ao tipo de repertório que empregam. Talvez uma palhaça esteja mais próxima a um palhaço do que de outra palhaça dependendo de seus recursos cênicos ${ }^{15}$. Em todo caso, as palhaças são vistas como mulheres e isso implica em uma série de significações estabelecidas

14 Para ilustrar essas afirmações: palhaços consagrados como Leo Bassi (Itália/Espanha) e Márcio Balas (Jogando no Quintal-SP), trabalham essencialmente com palavras e jogo de ideias e nem por isso sua atuação é prejudicada. Diversas outras falácias são levantadas para explicar as barreiras para atuação de mulheres na arte da palhaçaria que reiteram sempre os adjetivos comumente associados ao ser masculino (força, agressividade, atividade) e feminino (delicadeza, cuidado, passividade).

15 Ou seja, por exemplo, é mais provável que a palhaça Jasmim (Lily Curcio) esteja mais próxima à tipologia de Teotônio (Ricardo Puccetti), pois produz, como ele, uma comicidade mais corporal, sem falas, com trabalhos solo e de temperamento ingênuo do que da palhaça Rubra (Lu Lopes) que tem seu repertório baseado na fala e na música, além de uma personalidade mais debochada. 
sob seus corpos e comportamentos. Elas também compartilham experiências de vida diferente das dos homens justamente pelas coerções sociais, sendo assim, podem compartilhar de símbolos e significados comuns entre elas, gerando uma categoria palhaça, enquanto identidade, mas também como aliança.

Talvez seja o caso de pensar uma comicidade feminista? Ou seja, uma comicidade cujo sujeito, como explicou Teresa di Lauretis (1994), estaria dentro e fora da ideologia de gênero ${ }^{16}$. Ela compartilharia de símbolos e experiências que são próximas às mulheres pelo fato de serem mulheres. Porém, são mulheres diferentes entre si e que enxergam a construção do feminino como um invólucro e, assim, por meio de sua atuação cômica chegam a desconstruir e a reconstruir o que é tido como "feminino".

Enquanto representação do feminino, as palhaças produzem novas significações mesmo realizando os mesmo números e movimentos realizados por palhaços. Isso porque socialmente a representação de uma mulher resulta em diferentes entendimentos.

A extensa discussão sobre as questões de gênero traz a reflexão de que a presença das mulheres nessa arte modifica seus significados em diferentes níveis. Uma vez que as mulheres se colocam como sujeitos atuantes na palhaçaria, elas trazem novas corporalidades, novos motes para o improviso, a crítica ao local da mulher como o "outro" dentro da palhaçaria. Por fim, considerando a ambivalência do riso, a comicidade feminista tem a possibilidade de romper com as imposições das normas sociais para mulheres e, assim, produzir novas representações de gênero e reflexões para o público.

Enquanto corpo ligado ao grotesco, a arte da palhaçaria lida com as questões do baixo ventre, da sexualidade, da fome, da excreção. As palhaças jogam com a desproporção e a descontração, não precisam ser discretas e esperar o momento de falar. As palhaças podem ser sensuais, grotescas, inteligentes, bobas, sacanas, ingênuas, fortes, frágeis, feias e bonitas. Tudo ao mesmo tempo, porque elas são protagonistas dos seus corpos, de seus gestos, de suas dramaturgias. Elas têm a liberdade de criar, de mostrar as suas questões, a sua forma de ver o mundo e de improvisar com o público. Elas manipulam todas as suas qualidades e ações. E isso quebra com o que é imposto às mulheres socialmente, as mulheres "perfeitas", "gostosas", "belas, recatas e do lar".

A comicidade mostra-se criativa para lidar com diversas adversidades ao longo do tempo. Ela é crítica e subversiva. Portanto, entender o posicionamento marginal das mulheres diante da sociedade não se caracteriza como uma "falta", um “impedimento" ou um "fator limitante". Pelo contrário, essa posição de sujeito das mulheres palhaças oferece a elas - a nós! - ainda mais material para o trabalho. De

16 O conceito de ideologia de gênero aqui empregado não está ligado à onda conservadora que assola nosso país. Para nosso entendimento, o gênero funciona como uma ideologia, cuja "função (que a define) [é] de constituir indivíduos concretos em sujeitos" (LAURETIS, 1994: 212). Assim, o gênero, "como representação e como auto representação", é produto de diferentes tecnologias sociais como a mídia, os sistemas de educação, a família, práticas da vida cotidiana e até em instâncias nas quais se pretende estar em conflito com ele como as práticas artísticas e até mesmo no feminismo. 
alguma forma, todas as palhaças podem contribuir para a causa feminista, mesmo que isso passe despercebido para elas, pois lidam com o fato de serem mulheres por uma perspectiva fora do usual, do hegemônico ${ }^{17}$.

Fernando Chui Menezes (2011) faz uma análise da palhaça Judite - a artista Elena Cerântola, no espetáculo do Circo Vox - na qual descreve o corpo da palhaça como um corpo feminista, justamente por sua liberdade em lidar com o corpo e a sexualidade. Para ele, "o corpo exposto da mulher em seu desconcerto cômico traz ao picadeiro uma nova leitura sobre o corpo feminino" e assim poderia "dizer que foi a revolução feminista que possibilitou Judite" (Menezes, 2011: 165).

O autor revela ainda que a palhaça foi criticada em cursos de palhaçaria por exagerar em "caretas", mas que decidiu fazer a seu modo e, assim, descobrir "sua própria palhaça”. Dessa forma, por uma ação disruptiva da artista que ignora cânones e enxerga os espaços ainda não habitados para atuar, por meio do corpo e da intuição. Essa trajetória levou-a a ter êxito na principal característica da arte da palhaçaria: fazer rir. E, segundo Menezes, esse é o fator legitimador de sua atuação como palhaça.

Judite apresenta sinais de que o corpo feminino pode ser belo mesmo sem ser frágil e mesmo sem ser pornográfico, ser grotesco sem ser masculino e igualmente descobrir e revelar sua comicidade sem se preocupar com a sua obrigação cultural de sedução e erotismo. O surgimento do gênero "palhaça" no universo do circo traz a exposição do avesso do feminino, que não é necessariamente o masculino, mas algo que, de uma forma ou de outra, se forja na própria mulher. A negação do grotesco na figura da mulher é provavelmente um dos maiores asseguradores da cultura patriarcal, em que o ideal romântico deseja preservar a mulher sob a imagem divina, intocável e absolutamente distanciada de sua realidade política. No momento em que, na personagem Judite, o corpo da mulher rejeita o rótulo do feminino, ele imediatamente se torna um corpo feminista, ao pôr em xeque os valores objetais, depositados historicamente no corpo da mulher. Ao se colocar no lugar da pessoa que faz rir, ela inverte conceitos e adentra o território do poder de sedução pelo riso, atribuído historicamente apenas aos homens como instrumento de conquistas sexuais (Menezes, 2011: 166).

A presença das mulheres palhaças também causa uma fricção no repertório da arte da palhaçaria, uma vez que elas podem se recusar a repetir aquilo que lhes provoca a ideia de dor, sofrimento ou violência. Por exemplo, cenas que mostram situações que naturalizam a objetificação das mulheres, reforçam estereótipos ("mulher burra", "mulher feia e rejeitada", "mulher consumista”, rivalidade entre mulheres) e reiteram a cultura do estupro (como situações pretensamente engraçadas

17 Porém, mesmo como palhaça, é possível reproduzir estereótipos atribuídos às mulheres e/ou ridicularizar, no sentido satírico e destrutivo, o gênero feminino. 
nas quais as mulheres são enganadas para serem aproveitadas sexualmente). Essa revisão de repertóriocolabora para oxigenar as piadas e os esquetes com discursos que sedimentaram os valores da sociedade patriarcal/machista.

Essa consciência nos permite entender o quanto alguns tipos de riso desclassificam as mulheres e minorias, pertencendo à categoria de um riso de "castigo", de "humilhação", porque nos remetem à violência já sofrida por essas pessoas e que, portanto, não tem graça. Esse é sempre um cuidado que uma visão feminista fornece. E aí o feminismo não interessa só às mulheres, mas também aos homens, em busca de um riso que seja de comunhão, de subversão e de impulso para a vida.

\section{Voltando às noivas}

A intervenção artística Casada Consigo Mesma foi criada com o intuito de abordar as mulheres espectadoras de forma mais intimista, numa relação direta artista-público. $\mathrm{O}$ público aqui não é uma massa ou grande conjunto, mas uma pessoa convidada a participar do jogo de "casar-se consigo mesma". Essa pessoa, porém, está inserida no espaço público da rua. É a protagonista da cena, como no ritual do casamento, mas com suas testemunhas e convidadas/os. Assim, a cena se volta tanto para uma só pessoa quanto para um grupo e, consequentemente, a atuação das palhaças deve corresponder a esse movimento. São utilizados gestos e falas que alternam entre a expansão para o grupo como um todo e a atenção exclusiva para a "noiva" ou ainda desempenhos que congreguem as duas qualidades simultaneamente.

O roteiro criado partiu da ideia de programa performativo ${ }^{18}$, investigada por um grupo de diversas artistas que participaram da Ocupação Feminista, na Oficina Cultural Oswald de Andrade, promovida pelos coletivos Dodecafônico e Rubro Obsceno, em 2016. Durante a ocupação, uma das participantes, Bruna Edilamar, propôs transitar pelas ruas usando vestidobranco, pedalando uma bicicleta, com uma placa com dizeres"recém-casada comigo mesma”. Com o consentimento da artista, propusemos o programa para a Cia. Asfalto de Poesia, porém, sob a linguagem da palhaçaria, para experimentar uma prática de comicidade feminista feita por palhaças integrantes da companhia e convidadas.

Acrescentamos a interação direta com o público e o convite para participar da celebração e não apenas contemplá-la. Inserimos o espelho, elemento que permite o confronto entre a imagem que a mulher tem de si e a imagem refletida. E, por fim, exploramos o ritual do matrimônio por meio da ideia de paródia.

O roteiro criado visava deixar evidente, por meio da irreverência, algumas instituições, como mídias e família, que atuam como tecnologias de gênero e impõem às mulheres o casamento como símbolo de sucesso, como fórmula de felicidade.

18 O programa é o enunciado da performance: um conjunto de ações previamente estipuladas, claramente articuladas e conceitualmente polidas a ser realizado pelo artista, pelo público ou por ambos sem ensaio prévio. Ou seja, a temporalidade do programa é muito diferente daquela do espetáculo, do ensaio, da improvisação, da coreografia. (Fabião, 2013: 4) 
Quando as palhaças dizem "esse é o dia mais importante de sua vida”; "o dia que todos perguntavam quando seria”, "o dia do final de todas as novelas”; elas desvelam os discursos reproduzidos por essas instituições e que são absorvidos pelas mulheres.

A ação de olhar-se no espelho e responder "sim" à pergunta "você se aceita" é um exercício de autovalorização. Casar-se consigo seria desprender-se da necessidade de se sentir desejada e de ser valorada pelo olhar do outro. O espelho e olhar vidrado na própria imagem refletida remete à valorização de si de forma absoluta e não em relação ao desejo do homem.

Esse primeiro roteiro foi sendo aperfeiçoado conforme a realização das intervenções ${ }^{19}$ e a contribuição que cada palhaça - e também a interação com cada noiva. Por meio da improvisação, suas subjetividades e visões feministas foram incrementando o roteiro. Cada palhaça foi se apropriando dos elementos postos no jogo da cena e foi criando pequenas células cômicas dentro da linguagem da palhaçaria.

Ao mesmo tempo em que há a improvisação, sabe-se que essa só pode ser feita a partir de um repertório prévio. E é necessário se valer de elementos fundamentais da linguagem da palhaçaria para que a intervenção não se perca em conversas e gestos rotineiros, deixando o jogo em segundo plano. Sendo assim, o roteiro da intervenção é recheado de recursos cênicos próprios da linguagem como claques ${ }^{20}$, quedas, tropeções, choros trucados ${ }^{21}$, pequenas cenas cômicas combinadas. Por exemplo, as músicas em línguas ininteligíveis são recursos vocais da palhaçaria denominados grammelot $^{22}$.

Inclui-se, também, um diálogo no qual a musicalidade das palavras é base do efeito cômico. Nele, uma palhaça diz "Declaro-a casada-se consigo-se... se sismo mesma-se". Outra palhaça corrige a mestra de cerimônia: "Ca-sa-da con-si-go mesma!”. A primeira retruca: “é que eu não sei falar 'casada consigo mesma'!”. A primeira diz: "Aí, falou!". A segunda responde rapidamente: "é porque escorregou”! Nesse caso, o efeito cômico também é fruto da surpresa causada pela inicial incapacidade de fala, logo seguida de seu êxito inconsciente. Também são recorrentes as cenas nas quais uma das palhaças exalta-se demasiadamente e é repreendidada pelas outras,

19 Já realizamos a intervenção na Avenida Paulista Aberta; Virada feminista do Centro Cultural da Juventude; Virada feminista Casa de Cultura do Butantã; Virada Feminista da Escola Livre de Teatro; Sarau do Charles; Congresso Internacional de Humor Luso Hispânico - Chile; Centro de Convivência da Mulher, Capela do Socorro - São Paulo/SP; o Humano e o Urbano da Proxima Cia., São PauloSP ; Mostra Mulheres na Travessa II (São Paulo-SP); comemoração de 10 anos da Lei Maria da Penha (Secretaria de Direitos Humanos de São Paulo) ; Virada Sustentável de São Paulo.

20 Claques, expressão de origem francesa, são recursos cênicos que imitam tapas e bofetões, nos quais a personagem que finge levar o golpe também produz seu som por meio de palmas.

21 Tubos (canudos) de plástico que ficam apoiados atrás da orelha das artistas. Eles são ligados a uma bola de borracha que, ao ser apertada, esguicha água.

22 Segundo Dario Fo (2004), Grammelot é um jogo onomatopéico, que juntamente a gestos, ritmos e sonoridades particulares, é capaz de se assemelhar a uma estrutura vernacular e produzir um discurso compreensível de forma geral. $\mathrm{O}$ autor indica que as crianças produzem perfeitos grammelot quando se comunicam perfeitamente "quando fingem, por exemplo, realizar diálogos fluentes com um farfalhar espalhafatoso". É possível ainda realizar grammelot referentes a diferentes idiomas, dialetos e sotaques. 
mostrando seu desajuste, como uma marcha nupcial que se transforma em funk, devido a empolgação de uma das palhaças.

Dessa forma, mesmo com a intenção de provocar fricção e crítica em relação às questões do gênero feminino com o matrimônio, autoestima e amor próprio, não se pode perder de vista um dos mais relevantes traços da palhaçaria e da arte circense, a "arte de agradar" ${ }^{23}$. Dessa forma, a percepção da recepção do público é fundamental e retroalimenta a ação artística.

Novamente, o improviso torna-se fundamental para a intervenção. Mas não só improviso nos termos de ideias criativas e individuais que surgem de forma expontânea. Mas o improviso como capacidade devivenciar intensamente o momento presente e, assim, conseguir captar as reações do público e responder a elas. Esse momento de improvisação se dá no tempo presente, por meio do alongamento de cenas, da escolha de palavras, da movimentação, da postura corporal, dos gestos e da interação direta com o público.

Há uma grande necessidade de respeito, atenção e entendimento das pessoas e como elas se expõem ao que é dito, cada reação, sorriso, timidez ou resposta demonstra a abertura da participante. $\mathrm{O}$ objetivo é promover uma reflexão, mas ao mesmo tempo agradar, alegrar, descontrair. Acreditamos que esse também é um papel político da palhaçaria e, principalmente, aquela feita por mulheres e para mulheres. Promover o prazer do riso, em comunhão com as demais mulheres, sem ridicularizá-las, pode ser considerado como revolucionário.

A improvisação está presente o tempo todo durante a realização do trabalho. As artistas devem lidar com diversos tipos de respostas dadas pelo público. É preciso enfrentar a dificuldade de não se cair em estereótipos de gênero: é muito comum o público pensar que as palhaças vestidas de noivas estão "procurando marido", "foram rejeitadas por homens” e, por isso, casam-se consigo mesmas. Esse é um estereótipo muito comum na comédia: a da mulher que "ficou pra titia", uma "moçoila casadora", ou que está desesperada para encontrar um marido. As palhaças, neste caso, têm a função de subverter essa imagem tão sedimentada no imaginário do público.

Convida-se qualquer pessoa que se identifique com essa categoria, ou mesmo, quem não se identifica como mulher, mas apresenta um desejo sincero de realizar a cerimônia. Aqui fica uma ressalva, em algumas ocasiões, alguns homens que se disseram interessados em participar, mas com intenção sarcástica ou irônica e é nesse momento que as sacerdotizas-palhaças devem utilizar de seu poder - de quase exorcismo! - e impedir tamanha injúria ao ritual. Por outro lado, é comovente assistir ao casamento consigo realizado com crianças. "Se eu tivesse me casado comigo nessa idade, teria sido mais feliz”, comentou alguém do público.

23 A arte de agradar consiste na imensa capacidade de comunicação dos circenses com o público que o cerca, desde as relações no espetáculo até as relações com a cidade, no dia a dia dos circenses em sua itinerância. Essa qualidade dos artistas é fruto tanto da dependência econômica e política da aceitação da população e autoridades, quanto do caráter ritualístico da obra de arte circense que considera a participação, o respeito e o prazer do público como fatores essenciais. (DUARTE, 2015: 65-76) 
Em uma de nossas experiências, uma mulher respondeu abruptamente ao convite para casar-se consigo mesma: "não, eu gosto de homem". Outras ainda já responderam de forma indignada: "qual o problema de se casar com um homem?" As artistas também já foram acusadas de serem "coisas de esquerda”. São diversas as reações do público no espaço da rua e a palhaçaria, tem o desafio de contorná-las sem perder os elementos da linguagem, sem destruir o jogo criado.

Mesmo com as diversas significações do casamento na atualidade, na abertura para diversos tipos de relacionamento, ainda é marcante os resquícios de sua imposição para as mulheres. Assim, dialogar com a instituição do casamento por meio da paródia é uma questão delicada e são diversas as reações do público. Isso porque a paródia possuidupla função em relação ao seu referencial.

A paródia possui a instigante particularidade de conter a crítica no próprio ato artístico. Opera por uma abordagem criativa da tradição ou do passado em um processo de apropriação e recontextualização que instaura uma distância crítica. Para marcar a diferença, e não a semelhança. Trata-se menos de um gênero que de um gesto, que institui um ponto privilegiado de observação. Como um espelho falso, permite um olhar circular para o objeto, conforme se iluminem criação e/ou crítica (Metzler, 2015: 96).

A paródia ridiculariza, porém, também pode afirmar aquilo que é parodiado. Por isso, ela muitas vezes é autorizada e, ainda, pode se tornar uma espécie de homenagem. A imitação traz consigo uma crítica, mas também pode servir de reforço do que é parodiado (Metzler, 2015).

As palhaças, neste caso, estão sempre lidando com sutilezas do discurso cômico, que é polissêmico e pode ser interpretado de diferentes formas. A paródia é a forma lúdica de lidar com os padrões impostos socialmente, que pode ser interpretada como um desrespeito, uma crítica leve ou uma simples brincadeira, sem intenções definidas. Qualquer uma dessas interpretações interessam às artistas, pois incitam uma releitura da instituição do casamento.

\section{Conclusão}

A intervenção artística casada consigo mesma apresenta-se como experimentação de uma possível comicidade feminista. Isto é, uma comicidade que se reconhece como discurso político e que procura combater narrativas de naturalização da violência contra a mulher, como a cultura do estupro, a proliferação de estereótipos femininos, a submissão das mulheres aos homens e sua valorização de acordo com o desejo masculino. 
Mesmo conscientes de um discurso que sustenta sua atuação, ou seja, uma espécie de missão de sua ação artística, as palhaças preservam a linguagem própria da palhaçaria. A linguagem impõe um desempenho artístico que abarca a contradição, o ridículo de si e que não confronta ideias de forma direta e unívoca, mas de forma indireta, se valendo de metáforas, de ironias, de brincadeiras, de hipérboles e de outras atitudes não cotidianas.

Dessa forma, também notamos que, em eventos de cunho feministas, a intervenção não apresenta grandes impactos no que diz respeito à crítica à instituição do casamento ou qualquer questão de gênero, pois o público já está familiarizado com os temas. No entanto, ela é vista como alívio cômico, uma abordagem mais leve dos assuntos referentes às mulheres. Ela representa um contraponto para debates tão importantes, mas desgastantes emocionalmente, pois tratam de violência e opressão. Representa uma nova forma para o conteúdo. Por meio dessa linguagem, a discussão toma ares de celebração e união das pessoas por meio do cômico, tornando-se também uma pauta de reflexão feminista, pois defende o direito ao prazer do riso e da comunhão entre mulheres.

Quando se realiza a intervenção em locais onde a discussão de gênero não é dada,percebe-se uma maior abertura para se falar do temapor meio da descontração. A palhaçaria,enquanto linguagem popular, se aproxima do público de forma lúdica e pode cruzar algumas fronteiras de comportamento. A comicidade abre microfendas - milifissuras, nanorachas! - nas respostas automáticas em relação às questões das mulheres. Ela rompe, de maneira sutil a naturalização das tecnologias de gênero e, aos poucos, pode rasgá-las. Talvez não sozinha, mas em aliança com outras frentes de atuação.

Por se basear nos procedimentos da performance, ainda que adaptados, a intervenção torna-se contundente, com um caráterde urgência da arte em transformar-se em vida, no encontro das palhaças - e o melhor de si! - com quem se permite ser atravessada pelo próprio olhar no espelho.

Uma prática "acutilante" e humorada que chacoalha a separação entre arte e não-arte. Que lança o corpo do artista na urgência do mundo e a urgência do mundo no regime de atenção artístico. Uma prática do não ensaio. Um elogio à determinação do agente e à indeterminação da vida. Uma prática que exige tônus e flexibilidade, planejamento e abertura, disciplina e presença de espírito (Fabião, 2013: 10). 
Portanto, a experimentação de uma comicidade feminista para expressar um posicionamento político permite desvelar estruturas de opressão e apontar pontos de subversão. Assim, ela serve como um espelho às espectadoras e à própria artista e palhaça, refletindo novas possibilidades de vida ${ }^{24}$.

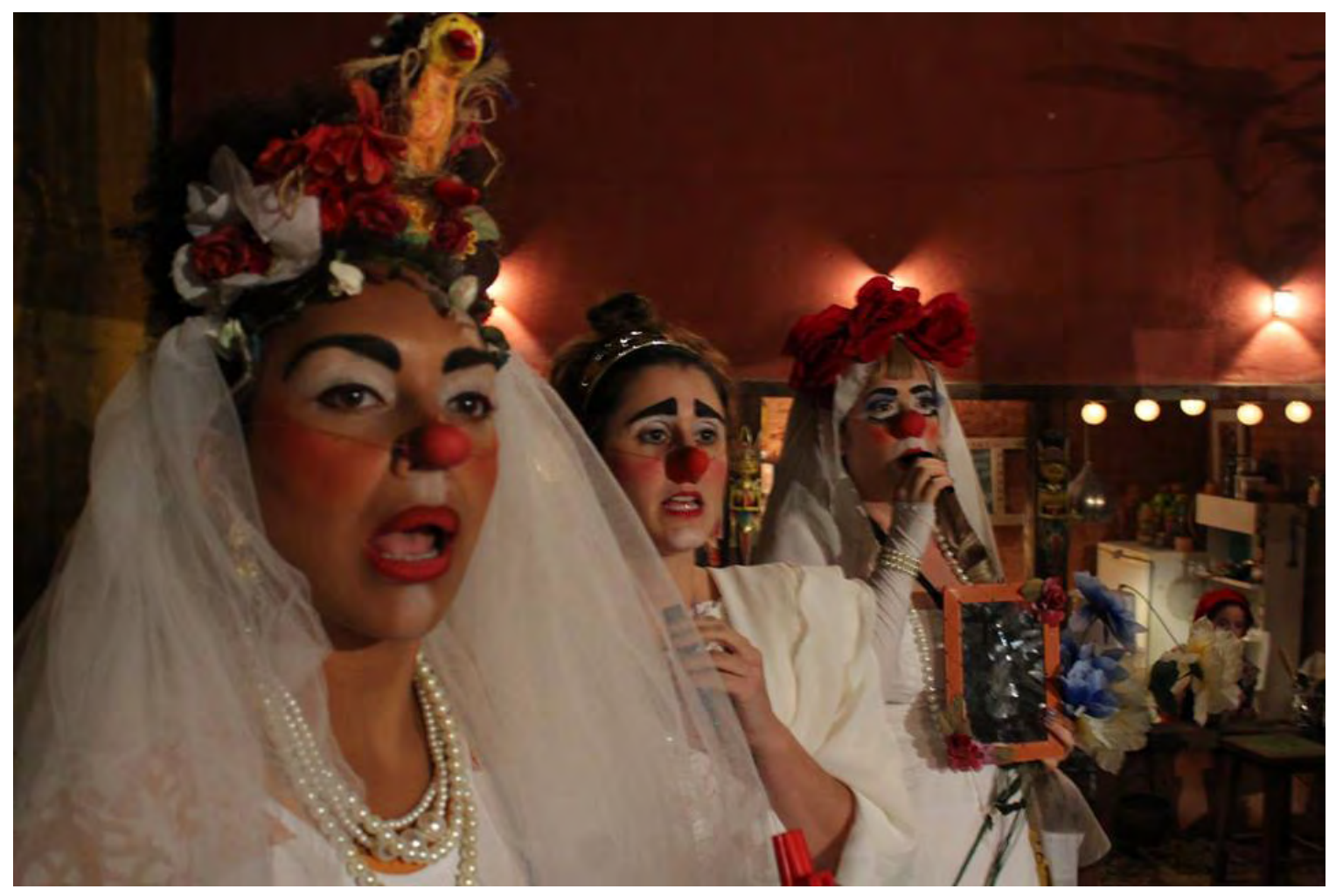

Figura 1- CASADA CONSIGO MESMA. (2016). Acervo da autora. Na foto: Mariá Guedes, Maria Silvia do Nascimento e Amanda Massaro.

\section{Referências Bibliográficas}

ALBERTI, Verena. (1995). "O riso, as paixões e as faculdades da alma”.Revista da PósGraduação em História da Universidade de Brasília. Brasília, UnB, v.3, n.1: p.5-25.

BAKHTIN, Mikhail. (2008). Trad. Yara Frateschi Vieira. A cultura popular na Idade Média e no Renascimento. 6a ed. São Paulo: Hucitec.

BERGSON, Henri. (2007). Trad. Ivone Castilho Benedetti. O riso - ensaio sobre a significação da comicidade. São Paulo: Martins Fontes.

24 Agradecimentos: agradeço ao meu querido primo Rafael do Nascimento Cesar pelo incentivo para este artigo. Ao meu orientador, Mario Fernando Bolognesi. À Lúcia Romano eà Cintia Lima Crescêncio pelas contribuições para minha pesquisa acadêmica. À Cia. Asfalto de Poesia pelas aventuras artísticas e parceria afetuosa. E a todas as mulheres que aceitaram cansar consigo mesmas. 
BOLOGNESI, Mário Fernando. (2003). Palhaços. São Paulo: UNESP.

, Mário Fernando. (2006). "Circo e teatro: aproximações e conflitos”. Sala Preta. Publicação do programa de pós-graduação em Artes Cênicas da ECA/USP, 2006, v.6: p. 9-19.

BURNIER, Luís Otávio. (2009). A arte de ator - da técnica à representação. $2^{\underline{a}}$ ed. Campinas, SP: Editora Unicamp.

CASADA CONSIGO MESMA. (2016). Criação: Cia. Asfalto de Poesia. Acervo da autora. 1 fotografia. Color.

DUARTE, Fernanda Jannuzzelli. (2015). O circo-teatro através dos tempos: cena e atuação no Pavilhão Arethuzza e no Circo de Teatro Tubinho. Dissertação (Mestrado em Teatro, Dança e Performance) Instituto de Artes, Universidade Estadual de Campinas (UNICAMP), Campinas-SP, arquivo digital.

FABIÃO, Eleonora. (2013). "Programa performativo: o corpo-em-experiência”. Revista do Lume - Núcleo Interdisciplinar de Pesquisas Teatrais UNICAMP, n. 4: p. 1-11.

FO, Dario; Franca Rame (organização). (2004). Trad. Lucas Baldovino, Carlos David Szlak. Manual mínimo do ator. $3^{\underline{a}}$ ed. São Paulo: Senac São Paulo.

KASPER, Kátia Maria. (2004). Experimentações clownescas: os palhaços e a criação de possibilidades de vida. Tese (Doutorado em Educação, Sociedade, Política e Cultura),Universidade Estadual de Campinas (UNICAMP), Campinas-SP, arquivo digital.

LAURETIS, Teresa de. (1994). A tecnologia do gênero. In BUARQUE DE HOLANDA, Heloísa. Tendências e impasses - o feminismo como crítica da cultura. Rio de Janeiro: Rocco.

MENEZES, Fernando Chui. (2011). "Quatro atos de Judite: o corpo feminista da palhaça”. Revista Trama Interdisciplinar. São Paulo, v.2, n.1: p. 161-168.

METZLER, Marta. (2015)."Espelho falso: a parodia na formação do teatro brasileiro”. Sala Preta. São Paulo: Universidade de São Paulo, v.15, n. 1: p. 87-98.

NASCIMENTO, Elaine Cristina Maia. (2014). Comicidade feminina: as possibilidades de construção do cômico no trabalho de mulheres palhaças. Dissertação (Mestradoem Artes Cênicas). Universidade Federal da Bahia, Salvador-BA, arquivo digital. 
NASCIMENTO, Maria Silvia do. (2017). Olha a palhaça no meio da praça: Lily Curcio, Lilian Moraes, questões de gênero e muito mais!. Dissertação (Mestrado em artes Estética e Poéticas cênicas). Universidade Estadual de São Paulo - Júlio de Mesquita Filho (UNESP), São Paulo-SP, arquivo digital.

SANTOS, Sarah Monteath dos. (2014). MulheresPalhaças: percursos históricos da palhaçaria feminina no Brasil. Dissertação (Mestrado em artes - Estética e Poéticas cênicas),Universidade Estadual de São Paulo - Júlio de Mesquita Filho (UNESP), São Paulo-SP, arquivo digital.

Recebido: 19.07.2018

Aceito: 10.10 .2018 